\title{
MANAGEMENT AND ADMINISTRATION
}

DOI https://doi.org/10.51647/kelm.2020.5.1.17

\section{METODYCZNE PODEJŚCIE DO OKREŚLENIA STRATEGII WIZERUNKOWEJ PRZEDSIĘBIORSTWA}

\author{
Valentyna Hatylo \\ starszy wyktadowca \\ Narodowego Uniwersytetu Lotniczego imienia N.E. Żukowskiego „Charkowski Instytut Lotniczy” \\ (Charków, Ukraina) \\ ORCID ID: 0000-0002-5518-9694 \\ Gatulo@ukr.net \\ Tetyana Calinescu \\ doktor nauk ekonomicznych, profesor, \\ kierownik Katedry Finansów, Rachunkowości i Opodatkowania Rachunkowości \\ Narodowego Uniwersytetu Lotniczego imienia N.E. Żukowskiego „Charkowski Instytut Lotniczy” \\ (Charków, Ukraina) \\ ORCID ID: 0000-0003-4919-5788
}

\begin{abstract}
Adnotacja. W artykule naukowym autorzy zaproponowały metodologię określania strategii wizerunkowej przedsiębiorstw w aspekcie analizy stanu składników wizerunku przedsiębiorstwa. Celem pracy jest zbadanie procesu tworzenia analitycznego zestawu narzędzi do badania stanu wizerunku przedsiębiorstwa i opracowania strategii wizerunkowej, określenie definicji „strategicznego wizerunku przedsiębiorstwa” i stworzenie głównych kierunków strategii wizerunkowej przedsiębiorstwa. Metody stosowane w badaniu: teoretyczną i metodologiczną podstawą badania stały się pozycje analizy systemowej, uogólnienia i analizy strategicznej. W pracy opracowano metodykę budowania strategii wizerunkowej w taki sposób, aby ocenić aktualny stan wizerunku przedsiębiorstwa, który składa się $\mathrm{z}$ wizerunku zewnętrznego (składniki rynkowe i klienckie) oraz wizerunku wewnętrznego (składniki kadrowe i produkcyjnoekonomiczne). Stworzenie pozytywnego wizerunku staje się nie tylko priorytetem, ale warunkiem koniecznym do osiągnięcia wzrostu gospodarczego i stabilizacji procesów gospodarczych w państwie w Warunkach neoindustrializacji. Wspólną oceną środków efektywnej działalności przedsiębiorstw w aspekcie strategii wizerunkowej będzie osiągnięcie głównego celu i taktycznych celów, a mianowicie: zdobycie określonej, dość stabilnej pozycji na rynku, zaspokojenie wymagań wszystkich uczestników rynku wobec przedsiębiorstwa, optymalizacja kosztów i stałe monitorowanie stanu wszystkich elementów wizerunku, skuteczności proponowanych działań taktycznych i zmiana współrzędnych strategii wizerunkowej na podstawie przeprowadzonej analizy.
\end{abstract}

Slowa kluczowe: strategia wizerunkowa, proces kształtowania wizerunku przedsiębiorstwa, pozytywny wizerunek

\section{METHODOLOGICAL APPROACHES TO THE DETERMINATION OF AN ENTERPRISE'S IMAGE STRATEGY}

\author{
Valentyna Hatylo \\ Assistant Lecturer \\ National Aerospace University "Kharkiv Aviation Institute" (Kharkiv, Ukraine) \\ ORCID ID: 0000-0002-5518-9694 \\ Gatulo@ukr.net \\ Tetyana Calinescu \\ Doctor of Economics, Professor, \\ Head of the Department of Finance, Accounting and Taxation \\ National Aerospace University "Kharkiv Aviation Institute" (Kharkiv, Ukraine) \\ ORCID ID: 0000-0003-4919-5788
}

\begin{abstract}
The authors provide a methodology for determining an enterprise's image strategy in terms of analysis of components of enterprise image. The purpose of the research is to explore the process of arranging analytical tools for analysis of the status of corporate image and development of an image strategy, to define "the image strategy of the enterprise" and elaborate the guidelines of the image strategy of the enterprise. The following methods have been used: theoretical and methodological framework relies on the provisions of system analysis, generalization
\end{abstract}


and strategic analysis. The article has elaborated a methodology for developing an image strategy in such a way as to assess the current state of the enterprise's image, which consists of an external image (market and customer components) and internal image (personnel and product-economic components). The cultivation of a positive image becomes not only a priority but a necessary condition for achieving economic growth and stabilization of economic processes taking place in the country amidst neo-industrialization. The general assessment of actions towards the effective performance of enterprises in the context of an image strategy involves meeting the primary purpose and its tactical objectives, as follows: to win a relatively stable position in the market, to satisfy the requirements forwarded by market participants to the enterprise, cost optimization and continuous monitoring of all components of the image, the effectiveness of the proposed tactical actions and a change of the coordinates of the image strategy according to the conducted analysis.

Key words: image strategy, development of image of enterprise, positive image.

\title{
МЕТОДИЧНІ ПІДХОДИ ДО ВИЗНАЧЕННЯ ІМІДЖЕВОЇ СТРАТЕГІЇ ПІДПРИСМСТВА
}

\author{
Валентина Гатило \\ старший викладач \\ Національного аерокосмічного університету імені М. С. Жуковського \\ «Харківський авіаиійний інститут» (Харків, Украйна) \\ ORCID ID: 0000-0002-5518-9694 \\ Gatulo@ukr.net \\ Тетяна Калінеску \\ доктор економічних наук, професор, \\ завідувачка кафедри фінансів, обліку і оподаткування \\ Наџіонального аерокосмічного університету імені М. С. Жуковського \\ «Харківський авіаиійний інститут» (Харків, Украӥна) \\ ORCID ID: 0000-0003-4919-5788
}

\begin{abstract}
Анотація. У науковій статті авторами запропоновано методику визначення іміджевої стратегії підприємств в аспекті аналізу стану складників іміджу підприємства. Мета роботи - дослідити процес формування аналітичного інструментарію дослідження стану іміджу підприємства і розробки іміджевої стратегії, визначити дефініцію «стратегічний імідж підприємства» та сформувати основні напрями іміджевої стратегії підприємства. Методи, використані в дослідженні: теоретичною і методологічною основою дослідження стали положення системного аналізу, узагальнення та стратегічного аналізу. У роботі розроблена методика побудована таким чином, щоб оцінити поточний стан іміджу підприємства, який складається із зовнішнього іміджу (ринковий і клієнтський складники) і внутрішнього іміджу (кадровий і виробничо-економічний складники). Створення позитивного іміджу стає не тільки першочерговим завданням, але необхідною умовою досягнення економічного зросту і стабілізації економічних процесів у державі в умовах неоіндустріалізації. Загальною оцінкою заходів щодо ефективної діяльності підприємств в аспекті іміджевої стратегії стане досягнення основної мети та її тактичних цілей, а саме: завоювання певної, досить стабільної позиції на ринку, задоволення вимог, що висувають до підприємства всі учасники ринку, оптимізація витрат та постійний моніторинг стану всіх складників іміджу, ефективності запропонованих тактичних дій і зміна координат іміджевої стратегії відповідно до проведеного аналізу.
\end{abstract}

Ключові слова: іміджева стратегія, процес формування іміджу підприємства, позитивний імідж.

Introduction. To implement the effective innovative-investment policy of an enterprise in the modern business environment, it is essential to develop and monitor the enterprise's image strategy continuously. The image strategy of the enterprise focuses on increasing the investment attractiveness of the company and allows using strategic mechanisms of the realization of its investment policy effectively.

The image strategy of the enterprise is an efficient tool for the achievement of its strategic goals covering the core activities; it focuses on a long-term perspective. The primary function of corporate image is the creation of a positive impression and attitude of customers, suppliers and stakeholders to business performance and its further development. The beforementioned will contribute to a high rating of the company, the consolidation of a market position, competitive recovery of the organization and profit markup. However, the system of making a positive image of the enterprise requires purposeful efforts to work out the image strategy of the enterprise that stipulates the relevance of this study.

The issues of the development of enterprises' image strategy and its role in the performance and business activity are the research focus of many specialists, namely: R. Brealey, S. Myers, H.V. Nazarova, B.Z. Milner, I.A. Khrabrova, G. Dowling, D. Doti, V.M. Beketov, V.I. Vieniedyktova, Yu.O. Plonska, O.M. Hriebieshkova, S.V. Horin, S. Sommersby, Ie.V. Romat, E.A. Utkin, R. Broom, Ph. Kotler, A. Center et al. Among the works of scientists, there are noteworthy studies devoted to the formation of a positive image of the enterprise. Thus, scientific papers (Lysov, 2016, Shvab, 2017) mark the effective development of an image strategy is a necessary condition for the enterprise's sustained and longterm business success. The paper by Dzhy (Dzhy, 2000) specifies a complex mechanism of creating a corporate image and describes the basic components of the image and its perception by society, as well as stipulates the rules of keeping 
a strong business image. Plakyda (Plakyda, 2010) considers the issue of the development of an image strategy to make an enterprise not only well-known but also sought-after.

The analysis of literature sources has shown that researchers regard the process of working out an enterprise's image strategy as part of the marketing strategy and generally associate it with the strategy of marketing communications. Individual types of image-building strategies and their characteristics are conveyed by four strategies, as follows (Fedorova, 2017: 670): "unique product", "unique organization", "unique personnel and leader" and "combined". However, such an approach lacks the holistic nature of the strategy, since attention is drawn to one of the aspects cultivating the corporate image. In analyzing the research devoted to the image, one can conclude the image is a dual economic category because it shall satisfy social demands and, at the same time, be individual. In other words, image perception is based on the contrast of a unified and unique image of the company as well. The very wellexecuted development of an image strategy allows making an enterprise more attractive for investors, increasing its capitalization, boosting income, strengthening its position when entering new markets. The creation of a positive image becomes not only a priority but a necessary condition for achieving economic growth and stabilization of economic processes taking place in the state under the environment of neo-industrialization.

The purpose of the research is to shape the methodological-analytical tools for assessing company image and elaborating its image strategy. The article sets the following tasks:

- to define "the strategic image of the enterprise";

- to form the basic elements of the enterprise's image strategy;

- to elaborate the tools for analysis and formulation of the enterprise's image strategy.

The following research methods have been used: system analysis, generalization and strategic analysis.

Main part. The development of an enterprise's image strategy is a purposeful activity to create a positive image that consists of all elements of strategic enterprise management. The principal stages of the process of forming the image strategy of the enterprise are as follows:

- studying and monitoring of the factors shaping corporate image;

- preparation of a concept of the image strategy of the enterprise;

- development of the image strategy of the enterprise;

- assessment of the outcome of the image strategy of the enterprise.

Thus, an advantageous solution of the tasks of a purposeful development of the image strategy of the enterprise in the modern context requires:

- a thorough analysis of the internal and external conditions of corporate activities;

- definition of the purposes of the development of the image strategy and substantiation of ways and means of its achievement.

It is distinguished the common image elements (Evalanov, 2010):

- a "first glance" image (first impression of a company);

- an intangible image (a client's response to service and attitude of company staff);

- an internal image ("ecosystem" within a company, an attitude of staff to the front-office policy);

- an external image (this is a set of the first three elements, taking into account a public opinion about the company).

Therefore, the basic components of the company's image should include a business image, social image, internal and corporate image.

The business image of the company consists of the visions of partners and customers of the company as a subject of a particular activity. The fundamental determinants of the image include goodwill or honesty (observance of business ethics) in carrying out a business activity, reliability, business partner loyalty, information transparency as well as business activity of the company, the indicators of which are sales volume, relative market share, a variety of goods, flexibility of pricing policy.

It is also worth noting that according to the assessment of state institutions, the enterprises' image comprises its vision by representatives of the regional administration, executive and legislative branches. The state institutions rely on the following assessment criteria: significance of the enterprise's products for the region, the degree of participation of the enterprise in regional social programs, the enterprise's implementation of national and regional laws, the number of jobs for residents of the region etc. (Shkardun, 2001).

The social image of the enterprise is the public idea of the social goals and the role of the enterprise in the economic, social and cultural life of society. The social image is formed through giving notices to the population about the social aspects of company activities, such as sponsorship, patronage, support of social movements, participation in solving environmental, employment, health care problems etc. (Shkardun, 2001).

The internal image of the enterprise gives personnel an idea about the organization. Moreover, the personnel are considered not only as a factor in the competitive capacity of the enterprise, one of the key community groups but also an important source of information about the enterprise for outside audiences. The core determinants of the internal image are corporate culture (a system of recruitment and personnel training, a system of social guarantees, a system of relations between executives and subordinates, a system of employee performance assessment based on the agreed criteria, a system of rewards, corporate identity) and socio-psychological climate (team's ambience and opinion, personal well-being and assessment of living and working conditions in a team) (Shkardun, 2001).

The corporate image is one of the tools for attaining the strategic goals of the enterprise related to its scope and focusing on the future. Benefits of the corporate image are evident. However, a positive image does not emerge intrinsically and does not exist per se (Shkardun, 2001). 
The determination of a strategy involves stating a strategic goal and ways of its achievement. In general terms, the strategic goal is to guarantee that kind of a result when the audience of the image would treat the object of the image as the customer would like. The problem of defining a strategic goal in the context of image-making is a comprehensive understanding of this goal. Otherwise, the actions associated with image-making will be inconsistent, chaotic and will have no effect because the lack of a well-defined strategic goal does not allow one to formulate the tasks clearly and develop a solid long-term plan of actions.

It is regarded (Lukianets, 2003) that a positive image is specified by the following indicators: reliability of an enterprise, openness and decency in relations with partners, the flexibility of conducting competition policy, professional customer service, morality of participation of the enterprise in various political, ecological and social actions, etc.

Thus, an enterprise's image is the compliance with modern requirements and criteria, the ability of the enterprise to meet actual consumer needs and provide such goods and services which conform to up-to-date standards, other requirements and challenges.

Advanced methods of developing the image strategy of the enterprise should include marketing communication tools, namely: PR, advertising, personal relations, sales promotion, sponsorship, creation of corporate identity, Internet promotion (Rohaleva, 2013: 46). These methods are used by modern enterprises without determining a strategic component. In the course of cultivating an image in the labor market, there is a fear this may not meet expectations and cause a decrease in the economic efficiency of the enterprise. The enterprise's image turns to be critically important, given the lack of highly-qualified personnel in the labor market.

Therefore, the USA and Europe continuously publish the rankings of the best employers, i.e. there are ratings of a reputational component of a company (Johnson, 2004). These ratings encourage manufacturers to improve the key performance indicators, service level. In the US, such measures merge into the category of corporate social responsibility (CSR) under the framework of the internal image, which is observed solely on the initiative of the business community (Illiashenko, 2016). In Europe, as a rule, the issues of business CSR are regulated by the norms, standards and legislations of the relevant countries. The Ukrainian image management policy stands in stark contrast to the European one that is shown in table 1.

Thus, review and analysis of the literature sources covering image management emphasize the relevance to study an image strategy of enterprises from various industries and the need in conceptual fundamentals of its management.

At the same time, the majority of modern methodological approaches to the formulation and use of image strategies don't have sufficient theoretical advances. First of all, the issue of determination of the process of developing the image strategy of enterprises in the labor market is poorly studied by scientists and has a fragmentary nature (Shavkun, 2016; Soroka, 2016).

Table 1

Features of enterprise image management in Ukraine and Europe

\begin{tabular}{|c|c|c|}
\hline $\begin{array}{c}\text { Indicators } \\
\end{array}$ & European Union & Ukraine \\
\hline $\begin{array}{l}\text { Key stakeholders in order of } \\
\text { importance. }\end{array}$ & $\begin{array}{l}\text { - Staff; } \\
\text { - Consumers; } \\
\text { - Society; } \\
\text { - Shareholders (owners). } \\
\end{array}$ & $\begin{array}{l}\text { - State; } \\
\text { - Shareholders (owners); } \\
\text { - Staff; } \\
\text { - Consumers. }\end{array}$ \\
\hline Drivers of image development. & $\begin{array}{l}\text { - The very enterprises; } \\
\text { - Non-profit organizations and society; } \\
\text { - State. }\end{array}$ & $\begin{array}{l}\text { - State; } \\
\text { - The very enterprises; } \\
\text { - Local authority. }\end{array}$ \\
\hline $\begin{array}{l}\text { Tendencies for CSR } \\
\text { implementation. }\end{array}$ & $\begin{array}{l}\text { - CSR is initiated by the very business; } \\
\text { - CSR standards are well-adapted and } \\
\text { widely used; } \\
\text { - CSR focuses on all stakeholders. }\end{array}$ & $\begin{array}{l}\text { - CSR is at the origin; } \\
\text { - It is often not regarded as an integral system, } \\
\text { and its benefits for the long run are depreciated; } \\
\text { - CSR is mostly oriented towards the state and } \\
\text { shareholders, and society to a lesser extent. }\end{array}$ \\
\hline
\end{tabular}

Source: (Odintseva, 2018)

One of the most common problems of the elaboration of the image strategy of enterprises from various sectors of the national economy is the lack of a uniform understanding of goals and objectives from the part of the staff. Moreover, the employees, the progress of a company depends on, often don't have the foggiest idea of the company's future. As a result, this leads to the fact that they can't defend the strategic interests of the enterprise under the framework of their professional capacity. Consequently, this adversely affects its image and performance results respectively (Shykhalova, 2012).

In the author's opinion (Shykhalova, 2012), the necessary conditions for the effective image strategy of enterprises belonging to various sectors of the national economy are as follows:

- first, positive performance results of economic entities in the form of manufacturing high-quality goods and providing quality services;

- secondly, realization of the problems associated with the formulation of the image strategy of enterprises in the market;

- thirdly, identification of the expectations and reactions of target audiences relevant to the actors;

- fourthly, establishment of strategic partnerships with the target audiences by the entities involved in economic or other activities; 
- fifthly, use, if necessary, of scientific-based and tried and tested technologies for the development of an image strategy.

Thus, the formulation of an effective image strategy in the context of strong corporate culture is of great importance for ensuring the sustainable development of enterprises in various sectors of the national economy and the building of a domestic system of an efficient image management strategy. The positive changes of socio-psychological fundamentals of corporate relations are a prerequisite for the favorable adaptation of domestic enterprises amidst neo-industrialization and information society. A lack of common objectives, unity and mutual understanding among market participants and deficiency of attractive business ideas and endeavors to grip the trends of the technological revolution significantly limit the opportunities for competitive growth of Ukrainian enterprises and the national economy in general.

Activities on working out an image strategy can also allow an enterprise to play in the market where competitors are not up to speed on its strategy. In such a case, the enterprise can use its image to demonstrate its intentions and development prospects to market participants.

The enterprise gains new opportunities in the market through improving image strategy management that provides the enterprise with a range of advantages:

- facilitating access to the external capital market;

- impairment of borrowed capital;

- enhancement of economic and financial efficiency of the company;

- protection against hostile takeover;

- improvement of company image.

The development of an enterprise's image strategy is a purposeful activity aimed at creating a positive image of the organization encompassing all components of enterprise image management. Nowadays, the issue of the formation of an organization's image strategy is poorly studied and thus, the working out of the stages of this process as a basis of delving into enterprise image is of great relevance. Relying on the available research, it is recommended defining the principal stages of the formulation of an image strategy of the enterprise in the following way (see Fig. 1):

- research and monitoring of the factors composing enterprise image;

- preparation of the concept of enterprise image strategy;

- development of enterprise image strategy;

- assessment of the efficiency of enterprise image strategy.

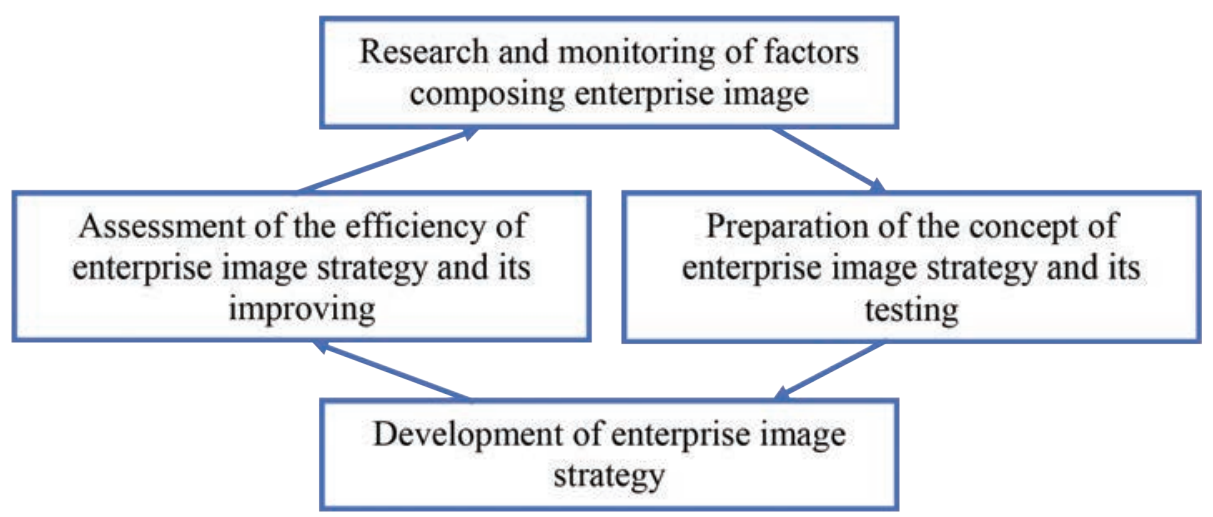

Fig. 1. The stages of the development of enterprise image

Source: the authors' development

The effectiveness of image strategies is one of the principal objectives of monitoring an enterprise's external environment.

To evaluate the effectiveness of image strategies, there should be established indicators of the economic efficiency of operative image-building actions for determining the feasibility of the chosen tools and directions of an image strategy. In general, a continuous improvement of the image strategy based on the monitoring and feedback will give a company the adaptive competitive advantages.

Taking into account the beforementioned in the research, one can conclude the development of a selection method for company image strategy is one of the priorities. There is a description of the elaborated selection method of business image strategy below.

According to the authors, to determine the state of image components, involving business image, social image and corporate image, it is essential to study the following components of enterprise image strategy: productiveeconomic, market, client and personnel ones.

The developed method is structured in such a way as to evaluate the current state of the company image, which comprises the external image (market and client components) and the internal image (personnel and productiveeconomic components). 
The first stage covers the development of the image profile of an enterprise, specification of all indicators that can be evaluated to gain data on the current state of the image's components. The indicators of income, profitability, technology level, fixed-capital assets, and business credit score may be applied to the productioneconomic component. To characterize the market component, the following indicators may be involved: company price level and its stability, competitive business advantages, market share. The client component can be characterized by a company's service level, loyalty system and discounts, PR level. Among the indicators of the personnel component, the following may be evaluated: a salary level compared to other companies in the same industry, employee turnover, employee motivation, professional development expenditures and social guarantees.

The second stage involves evaluating the state of every complex component of an image strategy. The evaluation of indicators is carried out according to a scale from 1 to 10 , where "1" means the worst state of the indicator, and " 10 " - the best state of the indicator. Both formalized and expert methods can be used to evaluate indicators, namely: semantic differential, focus groups, the Delphi method. Following the results of the second stage, the below table should be rendered (table 2).

Table 2

Indicators of the components of company image

\begin{tabular}{|c|c|c|c|}
\hline \multicolumn{2}{|c|}{ External environment (EE) } & \multicolumn{2}{|c|}{ Internal environment (IE) } \\
\hline \multicolumn{2}{|c|}{ Market scale (MS) } & \multicolumn{2}{|c|}{ Technical-economic scale (ES) } \\
\hline Indicator & Point & Indicator & Point \\
\hline Indicator 1 & & Indicator 1 & \\
\hline Indicator 2 & & Indicator 2 & \\
\hline$\ldots$ & & $\ldots$ & \\
\hline Total points & & Total points & \\
\hline \multicolumn{2}{|c|}{ Client scale (CS) } & \multicolumn{2}{|c|}{ Personnel scale (PS) } \\
\hline Indicator & Point & Indicator & Point \\
\hline Indicator 1 & & Indicator 1 & \\
\hline Indicator 2 & & Indicator 2 & \\
\hline$\ldots$ & & $\ldots$ & \\
\hline Total points & & Total points & \\
\hline
\end{tabular}

Source: the authors' development

The third stage encompasses the integral evaluation of two major components of company image. The evaluation is based on the global indicators

$$
\begin{gathered}
E E=M S_{i} \cdot W_{i}+C S_{j} \cdot V_{j}, \\
I E=E S n \cdot F n+P S_{m} \cdot E m,
\end{gathered}
$$

where $E E$ and $I E$ - global indicators of the image of the external and internal environments of the enterprise, respectively;

$M S_{i}, C S_{j}, E S_{n}, P S_{m}$ - single indicators characterizing the state of the market, client, technical-economic and personnel components of the enterprise, respectively;

$W_{i}, V_{i}, F_{n}, E_{m}$ - weight coefficients for the relevant single indicators of the components of enterprise image, the sum of weight coefficients should not exceed 1 upon each component.

The fourth stage builds a map of an enterprise's image

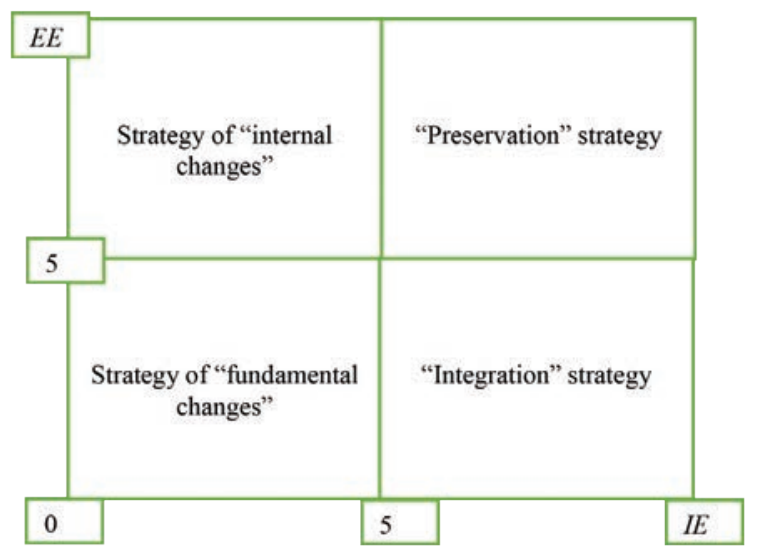

Fig. 2. A map of an enterprise's image strategy Source: the authors' development strategy. The map is a square divided into four parts according to the axes (Fig. 2).

The values driven from the calculations of the third stage are indicated on the axes; it is determined a square, a particular image strategy belongs to, at the crossing area of the coordinates.

At the fifth stage, one selects and more profoundly works out an image strategy of the enterprise. Every strategy is individually characterized by:

- the strategy of "fundamental changes" meets the strategy of entering a new business, or an enterprise has to develop its image both for a target audience of clients and partners in the context of dynamic changes of the external environment;

- "preservation" strategy corresponds to the state of the full-fledged image both in the external and internal environments. The prime objective of the image strategy is to hold the respective positions; 
- the strategy of "internal changes" is characterized by a disbalance between a market profile and critical problems in the corporate image. The central goals of this strategy are to develop the internal image;

- "integration" strategy characterizes a positive state of corporate image, but along with significant problems with the company's external image. In such a case, the strategic goals are focused on securing growth and market profile.

Strategic choice cannot be rigid and, in some cases, it is possible to combine the chosen strategies.

The sixth stage maintains the development of a comprehensive plan of the company's image strategy, which should include the following sections: finance, marketing, legal issues, ethical issues, economic efficiency of the strategy, production plan.

The key element of the effective image strategy involves a continuous monitoring of the state of all components of the image, efficiency of the proposed tactical actions and change of the coordinates of the image strategy in compliance to the conducted analysis.

Conclusions. Thus, by generalizing the research findings, one can conclude the following:

- a large number of applied issues related to the process of developing an image strategy of enterprises need constructive solutions;

- the development of an enterprise's image strategy is a purposeful activity on the cultivation of a positive image, which should be based on a thorough analysis of the external and internal operation environment of the enterprise and statement of the objectives for the formulation of the image strategy, substantiation of the ways and means of its accomplishment;

- this research has allowed the authors to justify the need to use the stages for the elaboration of an enterprise's image strategy and to develop a method of creating the image strategy of the enterprise, which aims at assessing the current state of enterprise image comprising external (market and customer components) and internal image (personnel and productive-economic components);

- elaborated methodological recommendations make it possible to organize a practical activity of an enterprise taking into account an image strategy, which results in gaining and maintaining new competitive advantages in the market.

\section{Bibliography:}

1. Джи Б. Имидж фирмы. Планирование, формирование, продвижение. Санкт-Петербург : Питер, 2000. 224 с.

2. Джонсон М. Битва за персонал. Москва : «Питер», 2004. 107 с.

3. Евланов Л.Г. Досвідчені оцінки знаходяться в управлінні. / Л.Г. Евланов, В.А. Кутузов. Москва : Економіка, 2010. 133 с.

4. Ілляшенко С.М. Роль іміджу у забезпеченні сталого розвитку промислових підприємств. Сталий розвиток XXI століття: управління, технології, моделі. Дискусії 2016 : монографія. / С.М. Ілляшенко, А.В. Колодка ; за наук. ред. д.е.н, проф. Є.В. Хлобистова. Інститут телекомунікацій та глобального інформаційного простору НАН України; НТТУ «Київський політехнічний інститут»; Вища економіко-гуманітарна школа. Черкаси : ВД Чабаненко Ю., 2016. C. $522-535$.

5. Лысов С. Четвертая промышленная революция. Эра кибер. По следам «Давос-2016». URL: http://sherlock-solutions. $\mathrm{com} /$ problem-solving-techniques/the-fourth-industrial-revolutionthe-era-of-cyber-in-the-footsteps-of-davos-2016.

6. Лук'янець Т.I. Рекламний менеджмент : навчальний посібник. Київ : КНЕУ, 2003. 440 с.

7. Одінцева С.В. Формування іміджу підприємства: світовий та вітчизняний досвід / С.В. Одінцева, Л.П. Артеменко. Актуальні проблеми економіки та управління : збірник наукових праць молодих учених. 2018. № 12. URL: http://ela.kpi.ua/handle/123456789/24621.

8. Шкардун В.Д. Оценка готовности предприятия к реализации маркетинговой стратегии / В.Д. Шкардун, Т.М. Ахтямов. Маркетинг. 2001. № 3. С. 79-86.

9. Плакида С.I., Митрохіна Ю.П. Імідж підприємства як фактор його конкурентоспроможності. URL: http://www.rusnauka.com/36_PWMN_2010/ Economics/ 76553.doc.htm.

10. Рогалева Н.Л. Современная концепция имиджа организации. Управление персоналом. 2013. № 1. С. 46.

11. Сорока О.В. HR-бренд: сутність та стан в Україні. Економіка і організація управління. 2016. № 3 (23). С. $293-301$. URL: http://jeou.donnu.edu.ua/article/view/2898.

12. Федорова В.А. Классификация стратегий формирования имиджа предприятия. Економіка $i$ суспільство. 2017. C. $668-672$.

13. Шавкун І.Г. Формування іміджу організації : навчальний посібник. / Запоріжжя : ЗНУ, 2016. 111 с.

14. Шваб К., Дэвис Н. Технологии Четвертой промышленной революции / пер. с англ. Москва : Бомбора : Эксмо, 2018. 317 с.

15. Шихальова А.С. Формування персоналу компанії засобами PR / А.С. Шихальова, Т.Г. Діброва. Актуальні проблеми економіки та управління : збірник наукових праць молодих вчених. 2012. № 6. URL: https://ela.kpi.ua/ handle/123456789/22633.

\section{References:}

1. Dzhi, B. (2000). Imidzh firmy. Planirovaniye, formirovaniye, prodvizheniye [Planning, shaping, promoting]. SanktPeterburg: Piter [in Russian].

2. Dzhonson, M. (2004). Bitva za personal [Personnel battle]. Moscow: Piter [in Russian].

3. Evlanov, L.H., \& Kutuzov, V.A. (2010). Dosvidcheni otsinky znakhodyat'sya v upravlinni [Experienced assessments are under management]. Moscow: Ekonomika [in Ukrainian].

4. Illiashenko, S.M., \& Kolodka, A.V. (2011). Rol imidzhu u zabezpechenni staloho rozvytku promyslovykh pidpryiemstv [The role of image in ensuring sustainable development of industrial enterprises]. Stalyi rozvytok - XXI stolittia: upravlinnia, tekhnolohii, modeli. Dyskusii 2016: monohrafiia, pp. 522-535. Cherkasy: VD Chabanenko Yu. [in Ukrainian]. 
5. Lysov, S. (2016). Chetvertaya promyshlennaya revolyutsiya. Era kiber. Po sledam "Davos-2016" [The fourth industrial revolution. The cyber era. In the footsteps of "Davos-2016"]. Retrieved from: http://sherlock-solutions.com/ problemsolving-techniques/the-fourth-industrial-revolutionthe-era-of-cyber-in-the-footsteps-of-davos-2016 [in Russian].

6. Lukianets, T.I. (2003). Reklamnyi menedzhment: navchalnyi posibnyk [Advertising management: textbook]. Kiev: KNEU [in Ukrainian].

7. Odintseva, S.V., \& Artemenko, L.P. (2018). Formuvannya imidzhu pidpryyemstva: svitovyy ta vitchyznyanyy dosvid [Forming the image of the enterprise: world and domestic experience]. Aktual'ni problemy ekonomiky ta upravlinnya: zbirnyk naukovykh prats' molodykh vchenykh, (12). Retrieved from: http://ela.kpi.ua/handle/123456789/24621 [in Ukrainian].

8. Shkardun, V.D., \& Ahtjamov, T.M. (2001). Ocenka gotovnosti predprijatija k realizacii marketingovoj strategii [Assessment of the readiness of an enterprise to implement a marketing strategy]. Marketing, 3, 79-86 [in Russian].

9. Plakyda, S.I., \& Mytrokhina, Yu. P. (2010). Imidzh pidpryyemstva yak faktor yoho konkurentospromozhnosti [The image of the enterprise as a factor of its competitiveness]. Retrieved from: http://www.rusnauka.com/36_PWMN_2010/ Economics/ 76553.doc.htm [in Ukrainian].

10. Rohaleva, N.L. (2013). Sovremennaya kontseptsyya ymydzha orhanyzatsyy [The image of the enterprise as a factor of its competitiveness]. Upravlenye personalom, 1, 46 [in Russian].

11. Soroka, O.V. (2016). HR-brend: sutnist' ta stan v Ukrayini [HR-brand: essence and state in Ukraine]. Ekonomika i orhanizatsiya upravlinnya, 3 (23), 293-301. Retrieved from: http://jeou.donnu.edu.ua/article/view/2898 [in Ukrainian].

12. Fedorova, V.A. (2017). Klassyfykatsyya stratehyy formyrovanyya ymydzha predpryyatyya [Classification of strategies for forming the image of the enterprise]. Ekonomika i suspil'stvo, 668-672 [in Russian].

13. Shavkun, I.H. (2016). Formuvannya imidzhu orhanizatsiyi [Forming the image of the organization]. Zaporizhzhya: ZNU [in Ukrainian].

14. Shvab, K., \& Djevis, N. (2018). Tehnologii Chetvertoj promyshlennoj revoljucii: per. s angl. [Technologies of the Fourth Industrial Revolution: lane. with English]. Moscow: Bombora: Jeksmo [in Russian].

15. Shykhal'ova, A.S. (2012). Formuvannya personalu kompaniyi zasobamy PR [Formation of the company's staff by means of PR]. Aktual'ni problemy ekonomiky ta upravlinnya: zbirnyk naukovykh prats' molodykh vchenykh, 6. Retrieved from: https://ela.kpi.ua/handle/123456789/22633 [in Ukrainian].

DOI https://doi.org/10.51647/kelm.2020.5.1.18

\title{
PRZESŁANKI MOŻLIWOŚCI ROZWOJU EKSPORTU NASION PRZEZ PODMIOTY, ZAJMUJĄCYCH SIĘ SELEKCJA I PRODUKCJĄ NASION ROŚLIN ZBOŻOWYCH UKRAINY
}

\author{
Iryna Danytko \\ Aspirant Wydziału Cen i Rynku Rolnego \\ Krajowe Centrum Badań ,Instytut Gospodarki Rolnictwa” (Kijów, Ukraina) \\ ORCID ID: 0000-0002-9551-1369 \\ i_danilko@meta.ua
}

Streszczenie. Ze strategicznego punktu widzenia dla poszczególnych podmiotów, zajmujących się selekcją i produkcją nasion roślin zbożowych, ważnym jest znalezienie różnych możliwości sprzedaży nasion po wyższej cenie. Jednym ze sposobów wykorzystania takiej możliwości jest ekspansja na zagraniczne rynki nasion. W artykule opisuje się instrumentarium (czterostopniowy algorytm) oceny przesłanek możliwości rozwoju eksportu nasion przez podmioty zajmujące się selekcją i produkcją nasion, który został wdrożony przez Nosiiwską Selekcyjno-Badawczą Stację Myroniwskiego Instytutu Pszenicy im. W. M. Remesła. Podstawą metodologiczną tego instrumentarium jest metoda indeksowa na podstawie obliczania wskaźników: RCA (Ujawnione przewagi komparatywne), RTA (Indeks relatywnej przewagi handlu), RHA (Indeks relatywnej przewagi importu), RMP (Wskaźnik penetracji importowej). Jej istotą jest porównywanie przewag handlowych państwa z możliwościami produkcyjnymi poszczególnych podmiotów, zajmujących się selekcją i produkcją nasion oraz stworzenie na podstawie tego strategii ich rozwoju.

Słowa kluczowe: przewagi handlowe państwa, strategia rozwoju, podmioty, zajmujące się selekcją i produkcja nasion, eksport nasion, algorytm uwzględniania przewag konkurencyjnych, konkurencyjność. 